\title{
Role of Serum Transferrin Receptor in Diagnosis of Iron Deficiency Anemia: Report of 130 Cases in West of Algeria
}

Beddek Fatima ${ }^{1,2}$ and Abbassia Demmouche ${ }^{2^{*}}$

${ }^{1}$ Central Laboratory of Biology, Hospital Establishment specializing in Obstetrics and Gynaecology, Sidi Bel Abbes, Algeria

${ }^{2}$ Department of Biology, Faculty of Science, University Djillali Liabes, BP 89, Faubourg Larbi Ben M'hidi 22000, Sidi Bel Abbes, Algeria

"Corresponding author: Abbassia Demmouche, Department of Biology, Faculty of Science, University Djillali Liabes, Sidi Bel Abbes, Algeria, Tel: +251-910-672-202; Fax: +213554586 382; E-mail: demmoucheabbassia@yahoo.fr

Received date: Jul 25, 2015, Accepted date: Sep 07, 2015, Publication date: Sep 11, 2015

Copyright: $\odot 2015$ Fatima B, et al. This is an open-access article distributed under the terms of the Creative Commons Attribution License, which permits unrestricted use, distribution, and reproduction in any medium, provided the original author and source are credited.

\section{Abstract}

Introduction: Anemia is one of the most common disorders in pregnancy. The most common cause is iron deficiency. Iron deficiency anemia is relatively easy to diagnose using a serum ferritin of $<15 \mathrm{ng} / \mathrm{ml}$. However, because ferritin is an acute phase reactant, the diagnosis of iron deficiency anemia in hospitalised or ill patients may be difficult, since serum ferritin may be normal or raised, even in the face of iron deficiency. Soluble transferrin receptor assay (sT-fR) may be useful in these situations because it reflects the degree of iron requirement in relation to supply, and it is not an acute phase reactant

Aim: The aims of our study are to affirm the value and specificity of sT-fR and integrate it in the list of routine parameters of iron status in the differential diagnosis of anemia in our laboratories in Algeria.

Patients and Method: Our study included 130 patients divided into three groups: control group with 40 healthy adult (22 men and 18 women). Group 2, with 30 patients (11 men and 19 women) hospitalized at the hematology department of the University Hospital "Abdelkader Hassani" of Sidi Bel Abbes, which represents the group of subjects with purely iron deficiency anemia without any associated disease (IDA) having rates of C-reactive protein (CRP $<10 \mathrm{mg} / \mathrm{L}$ ), and the third group with 60 anemic patients with anemia of chronic disease (ACD) (36 men and 24 women) hospitalized at the department of Internal Medicine of the University Hospital of Sidi Bel Abbes.

Each patient underwent a complete blood count, an iron status, and the ST-fR assays, and inflammatory balance $(\mathrm{CRP})$. All these examinations were performed immediately on fresh plasma and serum; assays were performed by immunoturbidimetric method.

Statistical analyzes of the data (mean and standard deviation, correlation coefficients, tests for normality and comparison of means) were performed using the software Statview (1998). A P-value $(P<0.05)$ was considered statistically significant, all $\mathrm{P}$ values are calculated by the t-test function using bilateral distribution.

Results: The control group (healthy subjects) has a normal iron status. All parameters with levels in normal ranges in both sexes for $100 \%$ of subjects.

The outcome of the second group is in perfect agreement with IDA for all of its parameters, it has a very disturbed iron status representative of this anemia: anemia $(\mathrm{Hb}<120 \mathrm{~g} / \mathrm{L}$ ); microcytosis (MCV $<80 \mathrm{fl}$ ); circulating pool (serum iron decreased high transferrinemia); reserves depleted (ferritin $<30 \mu \mathrm{g} / \mathrm{L}$ ) and erythropoietic needs high iron (high sT-fR). In the third group it's difficult to interpret ferritin levels (very higher), it's in contradiction with the other parameters, which leads us to discuss the homogeneity of this group. Because there is gender effect on key parameters of our study (hemoglobin, ferritin and sT-fR are heterogeneous in both sexes $(P<0.001)$, the results were analyzed separately between men and women. Analyses of results were done for discussing the sensitivity of the ST-fR on iron status and the informative contribution of each parameter to the specific diagnosis of anemia.

Conclusion: This study has allowed us to recommend for the use of sT-fR assays, because it is very promising for the exploration of erythropoiesis and the differential diagnosis of anemia in adults, with a normal range of: 2.65 to $4.39 \mathrm{mg} / \mathrm{L}$ in men and postmenopausal women and 2.03 to $3.69 \mathrm{mg} / \mathrm{L}$ in premenopausal women, in the hope of establishing an international range of reference values.

Keywords: Serum iron; Transferrin; sT-fR, Ferritin; Iron deficiency anemia; Inflammatory anemia; Iron status

\section{Introduction}

Iron deficiency is the leading cause of anemia in adults [1]. This is a major public health problem especially in developing countries where 
$60 \%$ of children with iron deficiency [2,3]. Anemia is one of the main deficiency diseases in the world and is characterized as a severe public health problem. The World Heelth Organization (WHO) estimates that anemia primarily affects 1.62 billion people worldwide and that the occurrence of iron deficiency is 2.5 fold higher [4].

Compared to ferritin, the sR-Tf present here a great interest in the very early diagnosis of martial deficiency right after the depletion of iron stores [5]. The diagnosis can be improved by calculating the ratio St-FR/log ferritin. This report is also of great diagnostic value because it tells us about the needs and iron stores [6].

\section{Patients and Methods}

Our study included 130 adult subjects divided into three research groups at the University Hospital "Abdelkader Hassani" of Sidi Bel Abbes (west Algeria).

The first group (control group), consisting of 40 adult subjects, 22 men (mean age $44.78 \pm 15.08$ years) and 18 women (mean age $46.50 \pm$ 12.67 years), were selected on the following criteria: an apparent good health, no history pathological individuals, haematologic, hepatic, renal and inflammatory normal.

The second group, with 30 adult subjects, 11 men (mean age $42.92 \pm$ 11.48 years), 19 women (mean age, $48.43 \pm 12.05$ years) hospitalized at the hematology department with microcytic hypochromic anemia whose recurrent Iron deficiency was originally retained with physical signs and improved hematological parameters (hemoglobin, mean corpuscular volume and mean corpuscular hemoglobin) in iron treatment $[7,8]$, with the rate of $\mathrm{C}$ reactive protein $(\mathrm{CRP}<10 \mathrm{mg} / \mathrm{L})$.

Another group of 60 patients, 36 men (mean age $51.36 \pm 12.12$ years), 24 women (mean age $51.68 \pm 10.31$ years) hospitalized at the
Department of Internal Medicine shows that the third group of anemic patients suffering from anemia of chronic disease (ACD) (Group 3). The installation of a chronic inflammatory reaction is defined as a rate of C-reactive protein level above $10 \mathrm{mg} / \mathrm{L}$ (CRP >10 mg/l) according to (Roche diagnostics).

All patients and controls received the same assessments: blood count with automated ADVIA 60 (Bayer Diagnostics). All parameters of iron status, inflammatory markers and sT-fR were measured by automated immunoturbidimetric assay on the (Diatron PICTUS 400) analyzer with the exception of serum iron measured by colorimetry Ferrozine (Spinreact) (usual values: 0.65 to $1.75 \mathrm{mg} / \mathrm{l}$ ).

TCF was calculated from sT-fR by the following formula: TCF $(\mu \mathrm{mol} / \mathrm{l})=\operatorname{TRF}(\mathrm{g} / \mathrm{l}) \times 25$ (usual values: from 50 to $90 \mu \mathrm{mol} / \mathrm{l})$ and coefficient of saturation transferrin (CTS) was calculated by the following formula: CTS $(\%)=$ Serum Iron $(\mathrm{SI})(\mu \mathrm{mol} / \mathrm{l}) \times 100 / \mathrm{TCF}$ ( $\mu \mathrm{mol} / \mathrm{l}$ ) (usual values: $25-35 \%$ ) [9].

Serum ferritin was assessed by immunoturbidimetry (Roche Diagnostics) (usual values: $20-250 \mathrm{mcg} / \mathrm{L}$ in men and 15 to $150 \mathrm{~g} / \mathrm{l}$ in women). The soluble transferrin receptor was measured by immunoturbidimetry (Dade Behring) (usual values: 0.83 to $1.76 \mathrm{mg} / \mathrm{l}$ ). (sTfR-Ft Index) was calculated by the following formula: $=\mathrm{sR}-\mathrm{fT}$ $(\mathrm{mg} / \mathrm{l}) / \log 10$ [Ft (ug/l)] (usual values: 1-4) [8,10,11]. Statistical analysis of data was performed using the Statview (1998) software. A P value $<0.05$ was considered statistically significant.

\section{Results and Discussion}

The results of iron status (complete blood count, serum iron, ferritin, transferrinemia and indices, the sT-fR and forefinger) of the three groups are summarized in Table 1.

\begin{tabular}{|c|c|c|c|c|c|c|}
\hline & \multicolumn{2}{|c|}{ Group 1 (control) $n=40$} & \multicolumn{2}{|c|}{ Group 2 (IDA) $n=30$} & \multicolumn{2}{|c|}{ Groupe $3(A C D) n=60$} \\
\hline & $\begin{array}{l}\text { Men } \\
\mathrm{n}=22\end{array}$ & Women $n=18$ & Men $n=11$ & Women $n=19$ & $\begin{array}{l}\text { Men } \\
n=36\end{array}$ & Women $n=24$ \\
\hline Age (years) & $43.78 \pm 15.08$ & $47.50 \pm 12.67$ & $40.92 \pm 11.48$ & $50.43 \pm 12.05$ & $52.36 \pm 12.12$ & $50.68 \pm 10.31$ \\
\hline Hemoglobin (g/l) & $140.05 \pm 5.91$ & $140.13 \pm 6.26$ & $102.05 \pm 6.24$ & $91.04 \pm 6.82$ & $92.46 \pm 5.38$ & $92.78 \pm 5.71$ \\
\hline MCV (fl) & $90.25 \pm 4.15$ & $84.38 \pm 3.15$ & $74.05 \pm 4.29$ & $68.33 \pm 3.45$ & $74.98 \pm 4.01$ & $69.65 \pm 2.82$ \\
\hline Hématocrit (\%) & $44.21 \pm 2.25$ & $42.21 \pm 2.49$ & $32.10 \pm 2.34$ & $28.11 \pm 2.73$ & $30.08 \pm 2.19$ & $28.48 \pm 2.25$ \\
\hline Serum iron $(\mu \mathrm{mol} / \mathrm{l})$ & $21.46 \pm 4.64$ & $18.02 \pm 5.67$ & $6.34 \pm 4.78$ & $5.52 \pm 3.65$ & $6.05 \pm 4.35$ & $5.71 \pm 3.32$ \\
\hline Ferritin $(\mu \mathrm{g} / \mathrm{l})$ & $207.16 \pm 46.40$ & $79.06 \pm 17.39$ & $27.04 \pm 6.40$ & $22.87 \pm 5.34$ & $367.25 \pm 71.33$ & $296.21 \pm 57.96$ \\
\hline Transferrin (mg/l) & $2.74 \pm 0.44$ & $2.77 \pm 0.51$ & $3.78 \pm 0.46$ & $3.76 \pm 0.55$ & $3.79 \pm 0.42$ & $3.70 \pm 0.47$ \\
\hline CTS (\%) & $31.42 \pm 12.78$ & $26.90 \pm 12.98$ & $8.54 \pm 6.48$ & $5.41 \pm 4.69$ & $8.05 \pm 5.83$ & $5.59 \pm 4.28$ \\
\hline $\operatorname{TCF}(\mu \mathrm{mol} \mathrm{Fe} / \mathrm{l})$ & $68.81 \pm 11.19$ & $69.13 \pm 12.71$ & $94.18 \pm 11.59$ & $94.57 \pm 13.76$ & $94.85 \pm 10.60$ & $92.58 \pm 11.86$ \\
\hline sR-fT (mg/l) & $3.52 \pm 0.87$ & $2.86 \pm 0.83$ & $8.53 \pm 0.92$ & $7.87 \pm 0.89$ & $5.34 \pm 2.30$ & $4.73 \pm 2.36$ \\
\hline sR-fT /Log(Ferritin) & $1.54 \pm 0.43$ & $1.55 \pm 0.54$ & $6.00 \pm 1.02$ & $6.05 \pm 1.27$ & $2.10 \pm 0.93$ & $1.95 \pm 1.02$ \\
\hline $\mathrm{CRP}(\mathrm{mg} / \mathrm{l})$ & $<10$ & $<10$ & $<10$ & $<10$ & >>10 & >>10 \\
\hline
\end{tabular}

Table 1: Values of the parameters of iron status and CRP in the control group and two groups of anemic subjects (results are expressed separately for both sexes). 
Citation: Fatima B, Demmouche A (2015) Role of Serum Transferrin Receptor in Diagnosis of Iron Deficiency Anemia: Report of 130 Cases in West of Algeria. J Blood Disord Transfus 6: 305. doi:10.4172/2155-9864.1000305

Page 3 of 6

The results are expressed as (mean $\pm \mathrm{SD}$ ), CRP (C-reactive protein) is compared with the threshold that indicates the installation of an inflammatory process $(10 \mathrm{mg} / \mathrm{L})$ value; group 1 (control or reference): healthy subjects; Group 2 (IDA): iron deficiency anemia; Group 3 (ACD): anemia of chronic disease; MCV: mean corpuscular volume; CTS: Coefficient of Transferrin Saturation; TCF: Total Capacity of Fixing the transferrin; sR-fT: Soluble Transferrin receptor.

\section{Study of the correlation of sR-fT with other parameters}

To estimate the sensitivity of the rate of sR-fT in iron status, the correlation between iron status parameters and sR-fT was evaluated and summarized in Table 2 .

\begin{tabular}{|c|c|c|c|c|c|c|}
\hline & \multicolumn{2}{|c|}{ Groupe 1 (control) $n=40$} & \multicolumn{2}{|c|}{ Groupe 2 (IDA) $n=30$} & \multicolumn{2}{|c|}{ Groupe 3 (ACD n=60 } \\
\hline & Men $n=22$ & Women $n=18$ & Men $n=11$ & Women $n=19$ & Men $n=36$ & Women $n=24$ \\
\hline Age (years) & -0.05 & -0.22 & -0.14 & -0.02 & -0.02 & -0.04 \\
\hline Hémoglobin (g/l) & -0.98 & -0.97 & -0.98 & -0.97 & -0.71 & -0.7 \\
\hline MCV (fl) & -0.96 & -0.91 & -0.97 & -0.92 & -0.68 & -0.67 \\
\hline Hématocrit (\%) & -0.93 & -0.95 & -0.94 & -0.96 & -0.67 & -0.7 \\
\hline Serum iron $(\mu \mathrm{mol} / \mathrm{l})$ & -0.98 & -0.98 & -0.98 & -0.97 & -0.72 & -0.68 \\
\hline Ferritin $(\mu \mathrm{g} / \mathrm{l})$ & -0.98 & -0.94 & -0.98 & -0.95 & -0.59 & -0.65 \\
\hline Transferrin (mg/l) & -0.98 & -0.98 & -0.98 & 0.99 & 0.7 & 0.7 \\
\hline CTS (\%) & -0.97 & -0.98 & -0.99 & -0.96 & -0.73 & -0.67 \\
\hline TCF $(\mu \mathrm{mol} \mathrm{Fe} / \mathrm{l})$ & -0.98 & -0.98 & -0.98 & 0.99 & -0.7 & -0.7 \\
\hline sR-fT (mg/l) & 1 & 1 & 1 & 1 & 1 & 1 \\
\hline sR-fT /Log(Ferritin) & 0.99 & 0.99 & 0.99 & 0.96 & 0.99 & 0.99 \\
\hline
\end{tabular}

Table 2: The values of correlation coefficients ( $r$ ) of the main parameters of iron status with the sR-fT in the control group and two groups of anemic subjects (results are expressed separately for both sexes). Negative values (r) indicate a negative correlation; positive values of (r) indicate a change in the same direction; group 1 (control or reference): healthy subjects; Group 2 (IDA): iron deficiency anemia; Group 3 (ACD): anemia of chronic disease; MCV: mean corpuscular volume; CTS: Coefficient of Transferrin Saturation; TCF: Total Capacity of Fixing the transferrin; sRfT: Soluble Transferrin receptor.

We note an excellent correlation between the main parameters of iron status with the sR-fT in both sexes (Table 2) for the control group and the group of subjects with iron deficiency anemia (IDA) absolute values ( $\mathrm{r}$ ) exceed 0.94 with a value $(\mathrm{P}<0.001)$, indicating the high sensitivity of this parameter to the iron status in the group subject to anemia of chronic disease (ACD), the correlation is relatively low for all parameters $(\mathrm{P}=0.12)$; which can be explained by the heterogeneity of this group. We also note the lack of correlation between the sR-fT and age, which excludes age as a factor influencing serum sR-fT in this population (adult).

\section{Study Informative Contributions of Each Parameter in the Specific Laboratory Diagnosis of Anemia's Studied}

\section{The contribution of haemoglobin}

For hemoglobin (Figure 1), a significant difference in hemoglobin ( $\mathrm{p}$ $<0.001$ ) was observed between the control group (M: $145.05 \pm 5.91 \mathrm{~g} / \mathrm{L}$, $\mathrm{W}: 135.13 \pm 6.26 \mathrm{~g} / \mathrm{L})$ and the two groups of anemic subjects (M: $100.05 \pm 6.24 \mathrm{~g} / \mathrm{L}, \mathrm{W}: 90.04 \pm 6.82 \mathrm{~g} / \mathrm{L})$ in subjects with IDA and (M: $99.46 \pm 5.38 \mathrm{~g} / \mathrm{L}, \mathrm{W}: 90.78 \pm 5.71 \mathrm{~g} / \mathrm{L})$ in patients at ACD: confirming appearance of anemia in patients of both groups but without any information on their pathophysiology.
This difference was significant $(\mathrm{P}>0.05)$ between the two groups anemic, as the lack of specificity assay of hemoglobin in the differential diagnosis of anemia limit its interest in the confirmation of ineffective erythropoiesis.

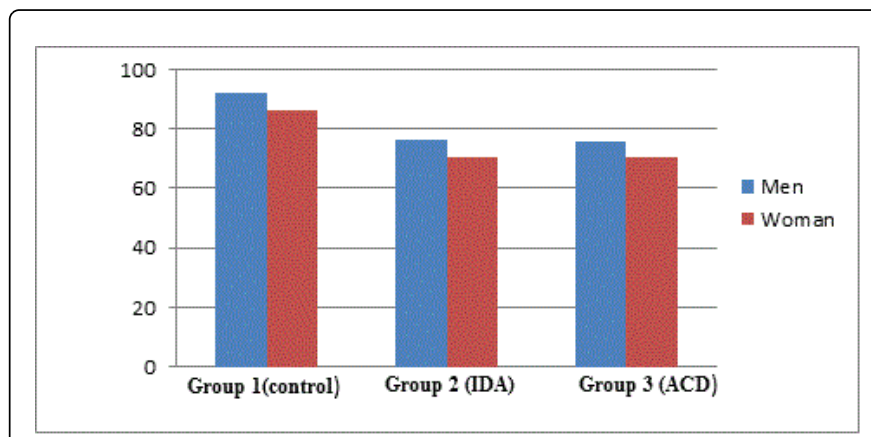

Figure 1: The hemoglobin $(\mathrm{Hb})$ in $\mathrm{g} / \mathrm{L}$ in group 1 (control) $(\mathrm{n}=40$ : $22 \mathrm{M} / 18 \mathrm{~W}$ ) and two groups of anemic subjects: Group 2 to iron deficiency anemia (IDA) $(\mathrm{n}=30: 11 \mathrm{M} / 19 \mathrm{~W})$; Group 3: anemia of chronic disease $(A C D)(n=60: 36 M / 24 W)$. 
Citation: Fatima B, Demmouche A (2015) Role of Serum Transferrin Receptor in Diagnosis of Iron Deficiency Anemia: Report of 130 Cases in West of Algeria. J Blood Disord Transfus 6: 305. doi:10.4172/2155-9864.1000305

Page 4 of 6

\section{The contribution of the mean corpuscular volume}

The difference in mean corpuscular volume between the control group (M: $92.25 \pm 4.15 \mathrm{fl}$, W: $86.38 \pm 3.15 \mathrm{fl}$ ) and the two groups with anemia (M: $76.05 \pm 4.29 \mathrm{fl}$, W: $70.33 \pm 3.45 \mathrm{fl})$ in subjects and IDA $(\mathrm{H}$ : $75.98 \pm 4.01 \mathrm{fl}, \mathrm{F}: 70.65 \pm 2.82 \mathrm{fl})$ in subjects with ACD can only indicate that anemia is microcytic no other information (Figure 2). An $\mathrm{MCV}<80 \mathrm{fl}$ is one of the signs of iron deficiency and/or inflammation anemia [12].

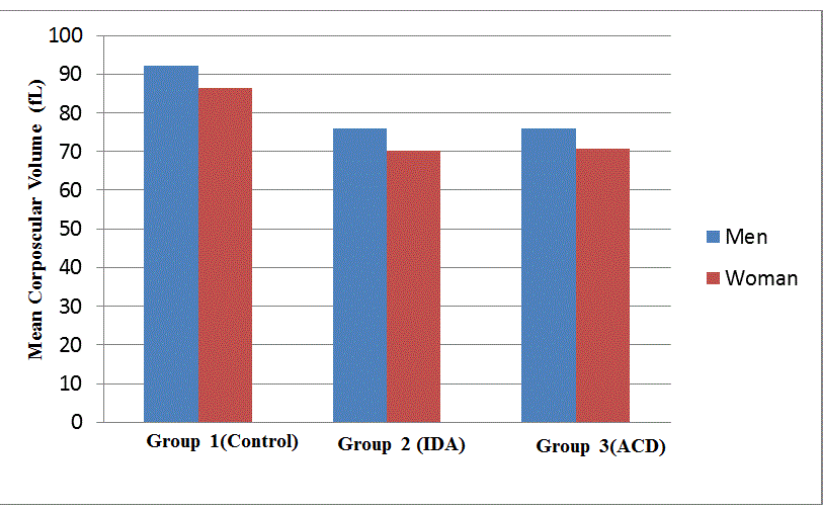

Figure 2: The values of mean corpuscular volume (MCV) in $\mathrm{fl}$ in the Group 1 (control) $(\mathrm{n}=40: 22 \mathrm{M} / 18 \mathrm{~W})$ and two groups of anemic subjects: Group 2 to iron deficiency anemia (IDA) $(\mathrm{n}=30: 11 \mathrm{M} / 19$ W); Group 3: anemia of chronic disease (ACD) ( $n=60: 36 \mathrm{M} / 24 \mathrm{~W})$.

\section{The contribution of serum iron}

Serum iron content may not be of any additional benefit, unless the diagnosis of hemoglobin confirmed a significant increase $(\mathrm{P}<0.001)$ in the circulating pool of iron in both anemic groups $(\mathrm{M}: 7.34 \pm 4.78$ $\mathrm{mmol} / \mathrm{L}, \mathrm{W}: 4.52 \pm 3.65 \mathrm{pmol} / \mathrm{L})$ in patients with IDA and $(\mathrm{M}: 7.05 \pm$ $4.35 \mathrm{pmol} / \mathrm{L}, \mathrm{W}: 471 \pm 3.32 \mathrm{pmol} / \mathrm{L}$ ) in patients with $\mathrm{ACD}$, compared to a group of healthy subjects (M: $20.46 \pm 4.64 \mathrm{mmol} / \mathrm{L}, \mathrm{W}: 17 \pm 0.02$ $5.67 \mathrm{umol} / \mathrm{L}$ ) (Figure 3). So serum iron is not a specific marker for the differential diagnosis of anemia. It gives an assessment of the mobilization of iron available for erythropoiesis.

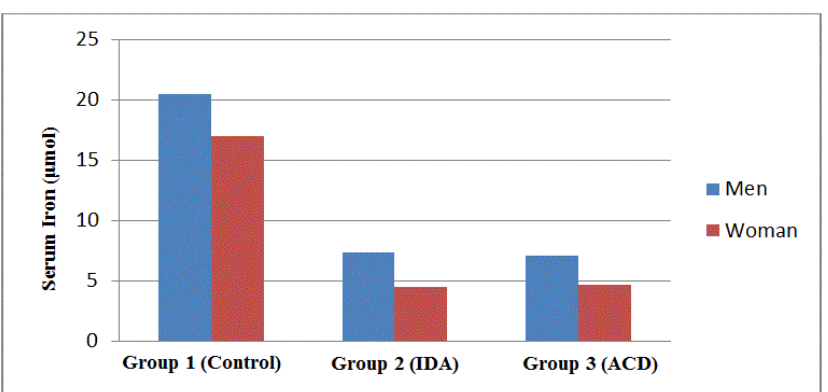

Figure 3: Concentrations of serum iron $(\mathrm{Fe}) \mu \mathrm{mol} / \mathrm{L}$ in group (control) (n=40: $22 \mathrm{M} / 18 \mathrm{~W})$ and two groups of anemic subjects: Group 2 to iron deficiency anemia (IDA) $(\mathrm{n}=30: 11 \mathrm{M} / 19 \mathrm{~W})$; Group 3: anemia of chronic disease (ACD) ( $n=60: 36 \mathrm{M} / 24 \mathrm{~W})$.

\section{The contribution of ferritin}

Ferritin gives a significant difference between the two groups of subjects with anemia (M: $28.04 \pm 6.40 \mathrm{mg} / \mathrm{L}, \mathrm{W}: 21.87 \pm 5.34 \mathrm{mg} / \mathrm{L})$ in patients with IDA $(\mathrm{P}<0.01)$ and $(\mathrm{M}: 369.25 \pm 71.33 \mathrm{mcg} / \mathrm{L}, \mathrm{W}: 294.21$ $\pm 57.96 \mathrm{mg} / \mathrm{L})$ in patients with $\mathrm{ACD}(\mathrm{P}<0.01)$ compared to the control group (M: $208.16 \pm 46.40 \mathrm{mg} / \mathrm{L}, \mathrm{W}: 78.06 \pm 17.39 \mathrm{mg} / \mathrm{L}$ ) (Figure 4). The difference is very significant between the two groups of subjects with anemia $(\mathrm{P}<0.01)$. Low ferritin in group 2 to say with indicates that this group is composed of subjects with pure iron deficiency anemia origin as it is in strong agreement with the hemoglobin and serum iron levels. But in the third group, high ferritin contradicts previous markers (low hemoglobin, and low serum iron) indicating iron deficiency. As against the ferritin indicates solid iron stores. This can be explained by the influence of the inflammatory process of ferritin, a protein of the acute phase response.

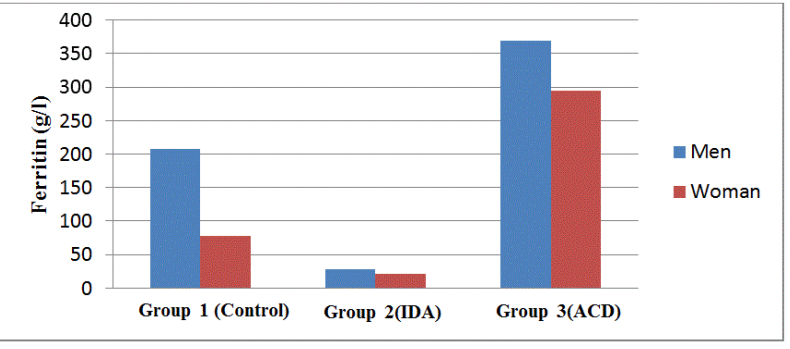

Figure 4: The concentrations of ferritin in $\mathrm{g} / \mathrm{L}$ in Group 1 (control) $(\mathrm{n}=40: 22 \mathrm{M} / 18 \mathrm{~W})$ and two groups of anemic subjects: Group 2 to iron deficiency anemia (IDA) $(\mathrm{n}=30: 11 \mathrm{M} / 19 \mathrm{~W})$; Group 3: anemia of chronic disease (ACD) ( $n=60: 36 \mathrm{M} / 24 \mathrm{~W})$.

\section{The contribution of sR-fT serum}

The rate of sT-fR is very high in group $2(\mathrm{M}: 8.53 \pm 0.92 \mathrm{mg} / \mathrm{L}$, W: $7.87 \pm 0.89 \mathrm{mg} / \mathrm{L}$ ) compared to the control group (M: $3.52 \pm 0.87$ $\mathrm{mg} / \mathrm{L}, \mathrm{W}: 2.86 \pm 0.83 \mathrm{mg} / \mathrm{L})$, a $(\mathrm{P}<0.001)$, confirming the high iron requirements in this group (deficient erythropoiesis in iron), (Figure 5). Indeed, in the third group the sT-fR is relatively high (M: $5.34 \pm$ $2.30 \mathrm{mg} / \mathrm{L}, \mathrm{W}: 4.73 \pm 2.36 \mathrm{mg} / \mathrm{L}$ ) compared to the control group $(\mathrm{P}<0.05)$, which leads us suggests that:

-Iron requirements in this group are lower;

-Are fluctuated from one patient to another (inter-individual variation).

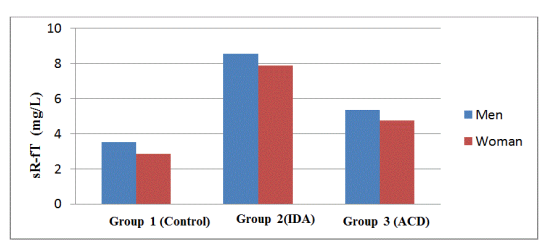

Figure 5: Concentrations of soluble transferrin receptor sT-fR in $\mathrm{mg} / \mathrm{L}$ in Group 1 (control) $(\mathrm{n}=40: 22 \mathrm{M} / 18 \mathrm{~W})$ and two groups of anemic subjects: Group 2 to iron deficiency anemia (IDA) $(n=30$ : $11 \mathrm{M} / 19 \mathrm{~W})$; Group 3: anemia of chronic disease (ACD) $(\mathrm{n}=60$ : $36 \mathrm{M} / 24 \mathrm{~W})$. 


\section{The contribution of sTfR-Ft Index}

The diagnostic performance is improved by calculating of the ratio sTfR/log ferritin (sTfR-Ft Index), This relationship between the concentration of sT-fR and decimal concentration of ferritin logarithm involves both parameters add at the same time reflect the functional pool (needs) and the reserve pool (stocks) iron respectively. Hence performances of the diagnosis are much improved [13].

The value of the index sTfR-Ft was significantly higher $(\mathrm{P}<0.001)$ in patients with iron deficiency anemia (IDA) (M: W 6.00 and 6.05) compared to healthy subjects ( $\mathrm{M}$ : and $1.54 \mathrm{~W}$ : 1.55$)$ reflecting the strong need and depletion of iron stores in these patients (Figure 6). But in patients with chronic diseases, its value is the same (M: $2.10 \mathrm{~W}$ and 1.95) that the sT-fR $(\mathrm{P}<0.05)$ than the control group $(\mathrm{M}: 1.54$ and $\mathrm{W}: 1.55)$, thus indicating that it needs not be so strong for iron, due to high levels of serum ferritin and possibly intra-series ST-FR change as has been suggested above. We also note that the value of this index is invariant between the sexes $(\mathrm{P}>0.05)$ since it is only a report of two parameters within the same sex.

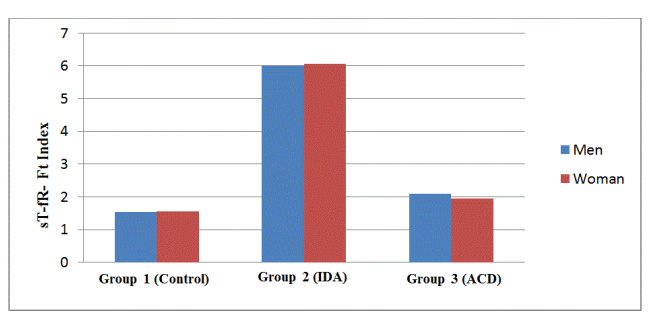

Figure 6: The values of the index-Rs Tf-Ft in Group 1 (control) $(n=40: 22 \mathrm{M} / 18 \mathrm{~W})$ and two groups of anemic subjects: Group 2 to iron deficiency anemia (IDA) $(\mathrm{n}=30: 11 \mathrm{M} / 19 \mathrm{~W})$; Group 3: anemia of chronic disease (ACD) $(n=60: 36 \mathrm{M} / 24 \mathrm{~W})$.

\section{Discussion}

Laboratory diagnosis of anemia typically based on a blood count to explore the severity of anemia ( $\mathrm{Hb}$ and $\mathrm{MCV}$ ) and other parameters of iron status in $70 \%$ of the iron status is not interpretable go beyond the exploration of iron stores by serum ferritin [14].

However these values may not be reliable, it uses more specific biomarkers, such as anemia associated with chronic inflammatory diseases, the most frequent cases where the differentiation between the possible causes of anemia is very difficult.

Hematologic markers (hemoglobin, mean corpuscular volume and mean corpuscular hemoglobin) just give an assessment of the severity of anemia [15].

However, these values may not be reliable, so you have to use more specific biomarkers in anemia associated with chronic inflammatory diseases, and in the most frequent cases where the differentiation among the possible causes of anemia is very difficult to interpret. While hematological markers (hemoglobin, mean corpuscular volume, mean corpuscular hemoglobin) will just give us an assessment of the severity of anemia [15].

In the case of pure iron deficiency, laboratory diagnosis is not going further than the serum ferritin, just to explore the state of iron stores. A serum ferritin levels below $30 \mathrm{ug} / \mathrm{l}$ is considered as evidence of inadequate iron stores (predictive value of iron deficiency anemia between 92-98\%) [13]. So ferritin is the biomarker of choice in the exploration of iron stores outside of chronic inflammatory disease. If serum ferritin is normal or diagnosis requires further investigation: it remains only to refer to the primary consideration is that the bone marrow puncture (Spinal Perls), the only technique used to explore the spinal cord iron stores. But it is rarely used because it is expensive and painful, that's why we always try to find a sensitive and specific technique, without too much inconvenience [16].

Here the interest of sT-fR can be utilized assays as a differential marker between the possible causes of anemia:

- A concentration of less than $4.39 \mathrm{mg} / \mathrm{L}$ for men and $3.69 \mathrm{mg} / \mathrm{L}$ for women, us toward anemia caused by disruption of erythropoiesis under the influence of inflammatory cytokines.

- A concentration greater than $4.39 \mathrm{mg} / \mathrm{L}$ for men and $3.69 \mathrm{mg} / \mathrm{L}$ in women move towards a combination of inflammatory anemia and iron deficiency [17].

\section{Conclusion}

This study allowed us to examine the serum transferrin receptor assays as a promising examination for the exploration of the intensity of erythropoiesis and differential diagnosis of anemia with a reference interval of 2.65 to $4.39 \mathrm{mg} / \mathrm{L}$ in men and postmenopausal women, and 2.03 to $3.69 \mathrm{mg} / \mathrm{L}$ in women of childbearing age.

In the hope of establishing international reference range of values references, the sT-fR measurement is a sensitive and a valuablenoninvasive tool for the diagnosis of iron depletion. It proves an attractive additional method to the conventional laboratory tests in the prediction of depleted iron pools in the anemic adult population.

\section{References}

1. Walter T (1994) Effect of iron-deficiency anaemia on cognitive skills in infancy and childhood. Baillieres Clin Haematol 7: 815-827.

2. Kuvibidila S, Warrier RP, Ode D, Yu L (1996) Serum transferrin receptor concentrations in women with mild malnutrition. Am J Clin Nutr 63: 596-601.

3. Andrews NC (1999) Disorders of iron metabolism. N Engl J Med 341: 1986-1995.

4. World Health Organization (WHO) (2008) Worldwide prevalence of anaemia 1993-2005: WHO global database on anaemia. Geneva: World Health Organization.

5. Guyatt GH, Oxman AD, Ali M, Willan A, McIlroy W, et al. (1992) Laboratory diagnosis of iron-deficiency anemia: an overview. J Gen Intern Med 7: 145-153.

6. Mast AE, Blinder MA, Gronowski AM, Chumley C, Scott MG (1998) Clinical utility of the soluble transferrin receptor and comparison with serum ferritin in several populations. Clin Chem 44: 45-51.

7. Fleming MD, Romano MA, Su MA, Garrick LM, Garrick MD, et al. (1998) Nramp2 is mutated in the anemic Belgrade (b) rat: evidence of a role for Nramp2 in endosomal iron transport. Proc Natl Acad Sci U S A 95: 1148-1153.

8. Ohgami RS, Campagna DR, Greer EL, Antiochos B, McDonald A, et al. (2005) Identification of a ferrireductase required for efficient transferrindependent iron uptake in erythroid cells. Nat Genet 37: 1264-1269.

9. Lim JE, Jin O, Bennett C, Morgan K, Wang F, et al. (2005) A mutation in Sec1511 causes anemia in hemoglobin deficit (hbd) mice. Nat Genet 37: 1270-1273.

10. Wilkins SJ, Frazer DM, Millard KN, McLaren GD, Anderson GJ, (2005) Iron metabolism in the hemoglobin deficit mouse: correlation of diferric transferrin with hepcidin expression. Blood 107: 1659-1664. 
Citation: Fatima B, Demmouche A (2015) Role of Serum Transferrin Receptor in Diagnosis of Iron Deficiency Anemia: Report of 130 Cases in West of Algeria. J Blood Disord Transfus 6: 305. doi:10.4172/2155-9864.1000305

Page 6 of 6

11. White RA, Boydston LA, Brookshier TR, McNulty SG, Nsumu NN, et al (2005) Iron metabolism mutant hbd mice have a deletion in Sec15l, which has homology to a yeast gene for vesicle docking. Genomics 86: 668-673.

12. Beyne-Rauzy O (2009) [Anemia of inflammation: Physiopathology and treatment]. Rev Med Interne 30 Suppl 4: S311-314.

13. Herklotz R, Huber AR (2010) Diagnostic de laboratoire des troubles du metabolisme du fer. Forum Med Suisse 10: 500-507.

14. R'zik S, Beguin Y (2001) Serum soluble transferrin receptor concentration is an accurate estimate of the mass of tissue receptors. Exp Hematol 29: 677-685.
15. Punnonen K, Irjala K, Rajamäki A (1994) Iron-deficiency anemia is associated with high concentrations of transferrin receptor in serum. Clin Chem 40: 774-776.

16. Punnonen K, Irjala K, Rajamäki A (1997) Serum transferrin receptor and its ratio to serum ferritin in the diagnosis of iron deficiency. Blood 89: 1052-1057.

17. Petterson T, Kivivuori SM, Siimes MA (1994) Is serum transferrin receptor useful for detecting iron-deficiency in anaemic patients with chronic inflammatory diseases?. Br J Rheumatol 33: 740-744. 